Volume 1 Nomor 1 - Februari 2019

ISSN 26560402

\title{
PENERAPAN MODEL PEMBELAJARAN KOOPERATIF TIPE TEAM ASSISTED INDIVIDUALIZATION (TAI) UNTUK MENINGKATKAN HASIL BELAJAR SISWA PADA MATERI FPB DAN KPK DI KELAS V SD NEGERI 10 KABANGKA
}

\author{
Muhammad Gazalidin UI haq ${ }^{1}$, Izlan Sentryo ${ }^{2}$ \\ ${ }^{1}$ Alumni Jurusan Pendidikan Guru Sekolah Dasar, FKIP Universitas Halu Oleo, \\ J1. H.E.A. Mokodompit Kendari 93232, Indonesia \\ ${ }^{2}$ Dosen FKIP Universitas Halu Oleo, Jl. H.E.A. Mokodompit Kendari 93232, \\ Indonesia \\ a)e-mail: mgazalidin@yahoo.com
}

\begin{abstract}
ABSTRAK
Penelitian ini bertujuan untuk meningkatkan hasil belajar siswa, aktivitas mengajar guru dan aktivitas belajar siswa dengan menerapkan model pembelajaran Kooperatif Tipe Team Assisted Individualization (TAI) pada materi faktor persekutuan terbesar dan kelipatan persekutuan terkecil di kelas V SD Negeri 10 Kabangka. Subjek penelitian ini adalah Guru dan siswa kelas V SD Negeri 10 Kabangka yang terdaftar pada Tahun Ajaran 2015/2016 dengan jumlah siswa 12 orang. Pelaksanaan tindakan mengikuti Prosedur penelitian yang terdiri dari: (1) perencanaan; (2) pelaksanaan tindakan; (3) observasi dan evaluasi; dan (4) refleksi. Penelitian tindakan kelas ini dilakukan dengan dua siklus, tiap siklus dilaksanakan dua kali pertemuan. Data dalam penelitian ini adalah data kualitatif adalah data aktifitas guru dan siswa dalam pembelajaran melalui lembar observasi dan data kuantitatif adalah hasil belajar siswa yang diperoleh melalui tes hasil belajar. Dari hasil penelitian menunjukkan, terjadi peningkatan hasil ketika guru menggunakan model pembelajaran kooperatif tipe TAI dalam pembelajaran faktor persekutuan terbesar dan kelipatan persekutuan terkecil siswa kelas V SD Negeri 10 Kabangka. Berdasarkan hasil tes siklus I, secara klasikal siswa yang memperoleh nilai ketuntasan sebanyak 7 orang atau 58,3\% dari 12 orang siswa dan sebanyak 5 orang atau 41,7\% dari 12 orang dengan nilai rata-rata 66,7. Pada siklus II ketuntasan belajar siswa secara klasikal meningkat menjadi 11 orang atau $91,7 \%$ dari 12 orang siswa yang tuntas dan 1 orang atau 8,3\% dari 12 orang yang tidak tuntas dengan nilai rata-rata 85,8 . Di samping itu skenario pembelajaran guru juga mencapai $80 \%$ pada siklus II. Berdasarkan hasil observasi dan evaluasi pada siklus II dalam penelitian ini telah mencapai indikator kinerja, maka dapat disimpulkan bahwa penggunaan model pembelajaran kooperatif tipe TAI pada materi faktor persekutuan terbesar dan kelipatan persekutuan terkecil dapat meningkatkan hasil belajar siswa kelas V SD Negeri 10 Kabangka.
\end{abstract}

Kata kunci: Hasil Belajar, Model Pembelajaran Kooperatif Tipe TAI, faktor persekutuan terbesar dan kelipatan persekutuan terkecil

\author{
APPLYING COOPERATIVE LEARNING MODEL TYPE TEAM ASSISTED \\ INDIVIDUALIZTIN (TAI) INCREASING STUDENTS LEARNED \\ RESULT BY ONSUBJECT THE GUILD FACTOR AND \\ MULTIPLES SMALLEST GUILD IN \\ CLASS V SDN 10 KABANGKA
}

\begin{abstract}
This study aims to improve student learning outcomes, teaching activities of teachers and students learning activities by implementing cooperative learning model type Team Assisted Individualization (TAI) on the material the greatest common factor and least common multiple in class V SD Negeri 10 Kabangka. The subjects were teachers and students
\end{abstract}


of class V SD Negeri 10 Kabangka enrolled in the school year of 2015/2016 with the number of students 12 people. Implementation of the action following the investigation procedure which consists of: (1) planning; (2) implementation of the action; (3) observation and evaluation; and (4) reflection. This classroom action research conducted by two cycles, each cycle held two meetings. The data in this study is qualitative data is data activities of teachers and students in learning through observation sheets and quantitative data are student learning outcomes obtained through achievement test. The results showed there was an increase results when teachers use cooperative learning TAI type of learning greatest common factor and least common multiple class V students of SD Negeri 10 Kabangka. Based on the test results of the first cycle, the classical students who received grades of completeness as many as 7 people or $58.3 \%$ of the 12 students and as many as 5 people or $41.7 \%$ of 12 people with an average value of 66.7. In the second cycle in the classical learning completeness students increased to 11 people or $91.7 \%$ of the 12 students who completed and 1 or $8.3 \%$ of the 12 people who did not complete the average value of 85.8. In addition, teacher learning scenarios also reached $80 \%$ in the second cycle. Based on observation and evaluation in the second cycle in this study have achieved performance indicators, it can be concluded that the use of cooperative learning model type TAI on the material the greatest common factor and least common multiple can improve learning outcomes fifth grade students of SD Negeri 10 Kabangka.

\section{Keywords: Results Learning, Cooperative Learning Model TAI, material the greatest common factor and least common multiple}

\section{Pendahuluan}

Dalam dunia pendidikan paradigma yang mengenal proses pembelajaran bersumber pada teori tabularasa john locke. John locke mengatakan bahwa pikiran seseorang adalah seperti kertas kosong putih bersih dan siap menunggu coretan-coretan gurunya. Dengan kata lain otak seorang anak adalah ibarat botol kosong yang siap diisi dengan ilmu pengetahuan dan kebijaksanaan pendidik. Paradigma lama adalah guru memberikan pengetahuan pada siswa yang pasif. Paradigma lama ini juga berarti jika seseorang mempunyai pengetahuan dan keahlian dalam suatu bidang, dia pasti akan dapat mengajar. Dia tidak perlu tahu mengenai seluk-beluk pembelajaran yang benar, akan tetapi dia hanya perlu menuangkan apa yang diketahuinya ke dalam "botol kosong" yang siap menerimanya (Asma, 2006: 1).

Dalam dunia pendidikan sekarang ini masih terdapat guru yang menganut paradigma lama ini, sebagai satu-satunya alternatif. Mereka mengajar dengan metode ceramah dan mengharapkan siswa duduk, diam, dengar, catat, dan hafal (3 DCH) serta mengadu siswa satu sama lain. Tuntutan dalam dunia pendidikan sudah banyak berubah. Kita tidak bisa lagi mempertahankan paradigma lama tersebut. Teori, penelitian dan pelaksanaan kegiatan pembelajaran membuktikan hahwa para guru sudah harus dapat mengubah paradigma pengajaran. Pendidik perlu menyusun dan melaksanakan kegiatan pembelajaran (Asma, 2006: 2).

Johnson dan Johnson (dalam Asma, 2006: 3) mencatat, banyak penelitian yang dilakukan terpisah oleh orang-orang yang berbeda dalam konteks berlainan mengenai metode pembelajaran kooperatif. Pada umumnya, hasil-hasil penelitian tersebut mendukung penggunaan model pembelajaran kooperatif. Data-data tersebut menunjukkan bahwa suasana belajar kooperatif menghasilkan prestasi yang lebih tinggi, hubungan yang lebih posotif dan penyesuaian psikologi yang lebih baik daripada suasana belajar yang penuh dengan persaingan dan memisah-misahkan siswa.

Model TAI dirancang dan digunakan untuk pembelajaran terprogram, Kelompok diorganisasi seperti halnya dengan model STAD dan TGT. Bedanya yaitu pada model STAD dan TGT menggunakan satu bentuk pembelajatan sedangkan model TAI menggunakan kombinasi pembelajaran 
kooperatif dan pengajaran Individual. Selain itu model STAD dan TGT dirancang untuk berbagai bidang studi, sedangkan pendekatan TAI dirancang khusus untuk pengajaran matematika kelas 3 sampai 6 (Asma, 2006: $55)$.

Dari hasil observasi awal di SD Negeri 10 Kabangka Kabupaten Muna pada bulan April 2015 khususnya di kelas V diperoleh keterangan dari guru bahwa nilai rata-rata siswa dari hasil ulangan semester ganjil tahun ajaran 2014/2015 adalah 60,00. Hal ini berarti bahwa pelajaran matematika masih rendah yakni dibawah nilai KKM (Kriteria Ketuntasan Minimal) yang ditetapkan di sekolah tersebut yaitu $\geq 65$ dari skor ideal 100 .

Rendahnya pencapaian nilai akhir siswa ini, menjadi indikasi bahwa pembelajaran yang dilakukan selama ini belum efektif. Salah satu kendala utamanya adalah dalam proses belajarmengajar antusias peserta didik untuk belajar sangat kurang, peserta didik lebih cenderung menerima apa saja yang disampaikan oleh guru, diam dan enggan mengemukakan pertanyaan maupun pendapat. Hal ini dikarenakan pembelajaran yang dilakukan oleh guru cenderung menggunakan metode pembelajaran konvensional yakni ceramah, tanya jawab dan pemberian tugas.

Salah satu alternatif untuk mengatasi masalah yang ada berupa penerapan model pembelajaran yang lebih mengutamakan keaktifan peserta didik dan memberi kesempatan peserta didik untuk mengembangkan potensinya secara maksimal. Model pembelajaran yang dimaksud adalah model pembelajaran kooperatif. Model pembelajaran kooperatif sangat cocok diterapkan pada pembelajaran matematika, karena dalam mempelajari matematika tidak cukup dengan hanya mengetahui dan menghafal konsep-konsep matematika, tetapi juga dibutuhkan suatu pemahaman serta kemampuan menyelesaikan persoalan matematika dengan baik dan benar.

Adapun tujuan penelitian ini adalah "Untuk meningkatkan hasil belajar siswa di kelas V SD Negeri 10 Kabangka melalui penerapan model pembelajaran kooperatif tipe TAI".

\section{Kajian Teori}

Menurut Dimyati dan Mudjiono (2002: 200) hasil belajar adalah tingkat keberhasilan yang dicapai oleh siswa setelah mengikuti suatu kegiatan pembelajaran, dimana tingkat keberhasilan tersebut kemudian ditandai dengan skala nilai huruf, kata atau simbol. Menurut Hamalik (2003: 15) hasil belajar tampak sebagai terjadinya perubahan tingkah laku pada diri siswa, yang dapat diamati dan diukur dalam bentuk perubahan pengetahuan, sikap dan keterampilan.

Arikunto (2003: 11) menyatakan tujuan pengukuran hasil belajar adalah sebagai berikut: (1) mengetahui tingkat penguasaan materi pelajaran yang dicapai oleh siswa dalam kurun waktu tertentu, (2) mengetahui posisi atau kedudukan siswa dalam kelompok kelasnya dan tingkat usaha yang dilakukan siswa dalam belajar dan (3) mengetahui tingkat dan daya guna model mengajar yang telah digunakan guru dalam proses belajar mengajar.

Model pembelajaran kooperative learning mempunyai manfaat-manfaat yang positif apabila diterapkan di ruang kelas. Beberapa keuntungannya antara lain: mengajarkan siswa menjadi percaya pada guru, kemampuan untuk berfikir, mencari informasi dari sumber lain dan belajar dari siswa lain; mendorong siswa untuk mengungkapkan idenya secara verbal dan membandingkan dengan ide temannya; dan membantu siswa belajar menghormati siswa yang pintar dan siswa yang lemah, juga menerima perbedaan ini. Ironisnya, model pembelajaran kooperatif belum banyak diterapkan dalam pendidikan walaupun orang Indonesia sangat membanggakan sifat gotong royong dalam kehidupan bermasyarakat (Wikipedia Bahasa Indonesia).

Ide utama dari belajar kooperatif adalah siswa bekerjasama untuk belajar dan bertanggung jawab pada kemajuan belajar temannya.Sebagai tambahan, belajar kooperatif menekankan pada tujuan dan kesuksesan kelompok Slavin (dalam Trianto, 2007: 57).

Menurut Asma (2006: 55) Model TAI menggunakan kombinasi pembelajaran kooperatif dan pengajaran individu. Widyantini (2006) menyatakan bahwa TAI dirancang untuk mengatasi kesulitan belajar siswa secara individual dan kegiatan pembelajarannya lebih banyak digunakan 
untuk pemecahan masalah. Dengan demikian melalui langkah-langkah TAI, proses belajar siswa meningkat karena sesuai dengan karakteristik pertumbuhan kejiwaan siswa.

\section{METODE PENELITIAN}

Jenis Penelitian

Jenis penelitian ini adalah Penelitian Tindakan Kelas (PTK). Penelitian Tindakan Kelas adalah penelitian yang dilakukan oleh guru di kelasnya sendiri dengan Cara (1) merencanakan, (2) melaksanakan dan (3) merefleksi tindakan secara kolaboratif dan partisipatif dengan tujuan memperbaiki kinerjanya sebagai guru, sehingga hasil belajar siswa dapat meningkat (Kusumah dan Dwitagama, 2010: 9). Menurut kardiawarman (dalam Paizaluddin dan Ermalinda, 2014: 6) Penelitian Tindakan Kelas (PTK) berasal dari bahasa inggris Classroom action research yang berarti penelitian yang dilakukan pada sebuah kelas untuk mengetahui akibat tindakan yang diterapkan pada suatu subjek penelitian di kelas tersebut

Faktor Yang Diteliti

1. Faktor siswa, untuk melihat apakah cara belajar siswa sudah baik atau belum. Selain itu dilihat pula hasil balajar siswa terhadap pemahaman FPB dan KPK yang diajarkan.

2. Faktor guru, melihat aktivitas guru bagaimana materi pelajaran disiapkan serta bagaimana model pembelajaran Kooperatif Tipe TAI dilaksanakan guru di dalam kelas.

Prosedur Penelitian

Prosedur dalam penelitian ini adalah sesuai dengan langkah-langkah PTK yaitu perencanaan, pelaksanaan tindakan, observasi, evaluasi dan refleksi. Penelitian tindakan kelas ini direncanakan terdiri dari dua siklus. Tiap siklus terdiri dari 2 kali pertemuan yang akan dilaksanakan sesuai dengan perubahan yang ingin dicapai, seperti apa yang telah didesain dalam faktor yang diselidiki.

Sumber, Jenis Data dan TeknikPengumpulan Data

1. Sumber Data

Sumber data dari penelitian ini adalah guru dan siswa.

2. Jenis Data

Jenis data dalam penelitian ini adalah:

a. Data kualitatif
Data kualitatif diperoleh melalui hasil observasi.

b. Data kuantitatif

Data ini diperoleh dari tes hasil belajar siswa pada masing-masing siklus.

3. Teknik Pengumpulan Data

Teknik pengumpulan data yang digunakan oleh peneliti yaitu:

a. Observasi

Observasi dilakukan dengan mengamati segala tindakan guru dan siswa pada saat berada di dalam kelas.

b. Tes Hasil Belajar

Tes hasil belajar dilakukan untuk mengukur tingkat pemahaman siswa tentang materi yang telah diajarkan. Tes hasil belajar diberikan pada saat akhir pembelajaran.

Analisis Data

Tehnik analisis data dalam penelitian ini adalah statistik deskriptif untuk menghitung nilai rata-rata hasil belajar siswa dalam tes siklus, menentukan persentase ketuntasan belajar secara klasikal dalam tes siklus, menentukan keberhasilan aktivitas belajar siswa, dan menentukan keberhasilan aktivitas mengajar guru. Data diuraikan secara deskriptif, yang selanjutnya dideskripsikan sesuai dengan tujuan penelitian. Tehnik analisis data tersebut dirumuskan sebagai berikut:

1. Untuk menentukan nilai siswa berdasarkan skor yang diperoleh siswa pada tes (kuis) digunakan rumus:

$$
\text { Nilai Siswa }=\frac{\text { Jumlah Skor siswa }}{\text { Skor Maksimum }} \times 100
$$

Nasution dan Suryanto (2007:

$$
\text { 4.22) }
$$

2. Menentukan nilai rata-rata

$$
\bar{M}=\frac{\sum x}{n}
$$

Keterangan:

$n=$ jumlah siswa secara keseluruhan

$\bar{M}=$ nilai rata-rata yang diperoleh siswa

$\sum x i=$ jumlah seluruh data

Suryanto, dkk (2009:

4.30)

3. Menghitung ketuntasan belajar klasikal

$\%$ tuntas $=\frac{\sum x i}{n} \times 100 \%$

Keterangan:

$\mathrm{n} \quad=\quad$ Jumlah siswa secara 
keseluruhan

$\Sigma x i=$ Jumlah siswa pada kategori ketuntasan belajar

Usman dan Setiawati ( dalam Hasmudin, 2012: 27)

4. Untuk menentukan keberhasilan aktivitas mengajar guru digunakan rumus:

$$
\% \text { Aktivitas }=\frac{\text { Skor Capaian }}{\text { Skor Maksimum }} \times 100 \%
$$

5. Untuk menentukan keberhasilan aktivitas belajar siswa digunakan rumus:

$$
\begin{gathered}
\% \text { Aktivitas }=\frac{\text { Skor Capaian }}{\text { Skor Maksimum }} \times 100 \% \\
\text { Nasution dan Suryanto }(2007:
\end{gathered}
$$

Indikator Kinerja

Indikator Kinerja dalam penelitian tindakan kelas pada materi pokok FPB dan KPK adalah:

1. Aktivitas mengajar guru dan aktivitas belajar siswa dikatakan baik apabila $\geq$ $80 \%$, aspek dalam rencana perbaikan pembelajaran telah terlaksana. (Poewanti dkk, 7: 7).

2. Hasil belajar Matematika siswa dinyatakan tuntas apabila $80 \%$ siswa telah mencapai nilai minimal 65, yang merupakan standar nilai KKM SD Negeri 10 Kabangka (Suryanto, 6: 21).

\section{HASIL PENELITIAN DAN PEMBAHASAN}

\section{Hasil Penelitian}

Data hasil observasi aktifitas mengajar guru pada siklus I ini, jumlah rata-rata skor hasil aktivitas mengajar guru adalah 21,5 dari skor maksimum 28. Sehingga persentase perolehan keterlaksanaan scenario pembelajaran diperoleh hasil $77 \%$.

Data hasil observasi aktifitas belajar siswa pada siklus I ini, jumlah rata-rata skor hasil aktivitas belajar siswa adalah 63,5 dari skor maksimum 84. Sehingga persentase perolehan keterlaksanaan scenario pembelajaran diperoleh hasil 75,5\%.

Berdasarkan data hasil tes siklus I dapat dijelaskan bahwa pelaksanaan pembelajaran pada materi FPB dan KPK melalui model pembelajaran kooperatif tipe (TAI) pada siswa kelas V SD Negeri 10 Kabangka menunjukan bahwa pemahaman sebagian siswa relatif rendah. Ini dapat dilihat dari hasil tes belajar siswa siklus I, dimana banyak siswa yang mendapat nilai tidak mencapai standar $\mathrm{KKM} \geq$ 65. Siswa yang memperoleh nilai mencapai KKM sebanyak 7 orang atau 58,3\% dan yang tidak mencapai KKM sebanyak 5 orang atau $41,7 \%$ dengan hasil belajar siswa mencapai rata- rata 66,7. Angka ini menunjukan masih perlu adanya refleksi perbaikan pembelajaran untuk dilaksanakan pada siklus selanjutnya karena mengingat bahwa indikator yang ditetapkan pada penelitian ini adalah $80 \%$ siswa telah mencapai Kriteria Ketuntasan Minimal (KKM) yaitu $\geq 65$.

Data hasil observasi aktifitas mengajar guru pada siklus I ini, rata-rata jumlah skor hasil aktivitas mengajar guru adalah 26 dari skor maksimum 28. Sehingga persentase perolehan keterlaksanaan scenario pembelajaran diperoleh hasil 92,5\%.

Pada siklus II siswa terlihat antusias dalam mengikuti pembelajaran.Ini disebabkan siswa sudah memahami model pembelajaran yang diterapkan. Data hasil observasi kegiatan belajar siswa pada siklus II rata-rata jumlah skor hasil aktivitas siswa yang dicapai adalah 77 dari skor maksimum 84. Sehingga persentase perolehan keterlaksanaan scenario pembelajaran diperoleh hasil 91,7\%.

Peneliti juga menganalisis dan merefleksi ketercapaian hasil belajar siswa dengan menggunakan model pembelajaran kooperatif tipe TAI, dimana berdasarkan data ketuntasan hasil belajar siswa pada siklus II terungkap bahwa secara klasikal hasil belajar siswa mengalami peningkatan dimana pada siklus I dari 12 siswa hanya 7 siswa yang mencapai nilai $\geq 65$ atau presentase ketuntasan adalah $58,3 \%$ dengan nilai rata-rata 66,7 sedangkan pada siklus II dari 12 siswa yang mencapai nilai $\mathrm{KKM} \geq 65$ atau presentase ketuntasan klasikal adalah $91,7 \%$ dengan nilai rata-rata 85,8 .

Berdasarkan nilai persentase ketuntasan klasikal yang dicapai pada siklus II yaitu $91,7 \%$ dengan nilai rata-rata 85,8 telah memenuhi standar Kriteria Ketuntasan Minimal, maka peneliti dan observer sepakat bahwa penelitian dihentikan sampai dengan siklus II.

\section{Pembahasan}

Berdasarkan analisis observasi guru selama kegiatan penelitian ini meliputi siklus I dan siklus II, siklus I terdiri dari dua kali pertemuan dan siklus II dua kali pertemuan 
diperoleh gambaran bahwa dalam kegiatan belajar mengajar dengan menerapkan model pembelajaran kooperatif tipe TAI dapat meningkatkan aktivitas belajar siswa dan aktifitas mengajar guru selama kegiatan bembelajaran berlangsung.

Pada siklus I guru dianggap sudah bisa melaksanakan kegiatan belajar mengajar sesuai dengan skenario pembelajaran, walaupun masih ada kekurangan dalam pelaksanaannya. Hal ini terlihat dari hasil observasi yang dilakukan guru yang menunjukkan masih ada hal-hal yang belum sepenuhnya terlaksana yang diberikan kepada siswa terhadap kegiatan belajar kelompok belum efektif sebagaimana diharapkan. Hal ini mengakibatkan ada siswasiswi tertentu yang cenderung mendominasi kegiatan belajar sehingga ada beberapa siswa yang hanya melihat-lihat saja. Dengan demikian, hanya sebagian siswa yang aktif dalam kelompoknya padahal yang diharapkan oleh guru adalah semua siswa aktif dan bersemangat dalam belajar serta menjalin kerjasama antar sesama anggota kelompok. Beberapa kekurangan ini terjadi karena guru kurang memfasilitasi siswa dengan baik dalam menerapkan model pembelajaran kooperatif tipe TAI dalam kegiatan pembelajaran serta kurang mampu dalam membangkitkan keterlibatan siswa secara optimal dalam pembelajaran.

Beberapa kekurangan pada siklus I kemudian direfleksi dan dilakukan perbaikanperbaikan untuk pelaksanaan tindakan pada siklus II. Hasil refleksi tersebut menjadi pedoman dalam pelaksanaan siklus II. Pada pelaksanaan tindakan siklus II terlihat ada kemajuan. Beberapa kelemahan dari siklus I sudah dapat diperbaiki, sehingga pelaksanaan kegiatan pembelajaran terlaksana dengan tepat dan sistematis sesuai dengan skenario pembelajaran.

Dari tes hasil belajar siswa pada siklus I siswa secara klasikal dengan persentase ketuntasan yaitu $58,3 \%$ atau 7 orang siswa yang telah memperoleh nilai $\geq 65$ dengan nilai rata-rata 66,7. Ketuntasan ini belum mencapai indikator keberhasilan dalam penelitian ini yaitu $80 \%$. Rendahnya hasil belajar siswa pada siklus I ini disebabkan oleh rendahnya aktivitas siswa pada beberapa anggota pada setiap kelompok. Sedangkan pada siklus II target ketuntasan siswa telah tercapai yaitu
91,7\% atau sebanyak 11 orang siswa telah memperoleh nilai $\geq 65$ dengan nilai rata-rata 85,8 . Berdasarkan tes hasil belajar yang dicapai oleh siswa pada siklus II telah mengalami peningkatan yaitu dari 58,3\% siswa yang tuntas belajar meningkat menjadi $91,7 \%$. Terjadinya peningkatan persentase ketuntasan pada siklus II peneliti dianggap telah berhasil mencapai targetnya dalam penelitian ini. Keberhasilan siswa dalam tes hasil belajar ini memberikan gambaran bahwa dengan menerapkan model pembelajaran kooperatif tipe TAI mampu meningkatkan hasil belajar siswa. Hal ini karena dalam penerapannya pembelajaran TAI mampu meningkatkan motivasi belajar siswa terhadap materi pembelajaran sehingga siswa aktif dalam mengikuti proses pembelajaran. Dampak dari siswa ini akan mendorong siswa untuk lebih berusaha meningkatkan aktifitas belajarnya sehingga penguasaan siswa terhadap materi yang diajarkan menjadi optimal.

Berdasarkan analisis data observasi siswa selama proses pembelajaran siklus I dan siklus II menunjukan gambaran bahwa penerapan model pembelajaran kooperatif TAI pada materi FPB dan KPK kelas V SD Negeri 10 Kabangka ada peningkatan aktivitas belajar siswa. Pada siklus I aktivitas belajar siswa dianggap baik walaupun masih banyak terdapat kekurangan-kekurangan seperti ada sebagian siswa yang tidak memperhatikan penjelasan guru karena guru menjelaskan dengan cepat dan membuat siswa yang kurang mengerti terhadap penjelasan guru menjadi bosan, ada beberapa siswa yang kurang aktif dalam kelompoknya baik dalam pembelajaran maupun dalam mengerjakan soal-soal, selain itu juga terdapat siswa yang lebih asyik bermain dan bercerita. Beberapa kekurangan itu kemudian direfleksi dan dilakukan beberapa perbaikan untuk pelaksanaan tindakan pada siklus II. Sehingga kegiatan pembelajaran pada siklus II berjalan dengan sangat baik. Hal ini nampak dengan keaktifan siswa dalam kegiatan pelaksanaan pembelajaran pada siklus II.

Dari uraian di atas, maka proses pembelajaran dengan menerapkan model pembelajaran kooperatif tipe TAI dalam penelitian ini, dikatakan mampu meningkatkan keaktifan setiap siswa dalam proses pembelajaran, menyelesaikan masalah, 
berpikir kritis dan saling bekerjasama, sehingga hasil belajar siswa dapat ditingkatkan, bukan saja kemampuan kognitifnya tetapi juga kemampuan afektif dan psikomotornya sehingga proses pembelajaran yang dilahirkan benar-benar mencerminkan pembelajaran yang efektif dan efisien.

\section{PENUTUP}

Kesimpulan

Hasil belajar siswa kelas V SD Negeri 10 Kabangka pada materi FPB dan KPK dapat ditingkatkan melalui model pembelajaran kooperatif tipe TAI, dimana pada siklus I hasil belajar siswa pada ketuntasan klasikal sebesar $58,3 \%$ dengan nilai rata-rata 66,7 sedangkan pada siklus II hasil belajar siswa pada ketuntasan klasikal mengalami peningkatan menjadi $91,7 \%$ atau 11 siswa yang tuntas dengan rata-rata 85,8 .

Saran

Berdasarkan penelitian yang telah dilakukan, maka peneliti menyarankan hal-hal sebagai berikut:

1. Pada saat pelaksanaan pembelajaran, peneliti harus lebih memperhatikan penggunaan waktu agar pembelajaran lebih optimal, karena dalam penerapan model pembelajaran kooperatif tipe TAI, pada langkah tertentu waktu yang diperlukan cukup banyak dari biasanya. Contohnya pada saat pemberian penghargaan kelompok di akhir pembelajaran.

2. Pada pembagian kelompok hendaknya dilakukan sebelum pelaksanaan pembelajaran di kelas agar pada saat proses pembelajaran peneliti tidak mengalami kesulitan dalam membagi kelompok.

3. Hendaknya peneliti benar-benar mengetahui kemampuan awal siswa sehingga siswa benar-benar terbagi dalam kelompok yang heterogen.

4. Peneliti hendaknya lebih memperhatikan siswa dalam kelompoknya karena tidak semua siswa mau menerima anggota kelompok yang tidak Ia sukai, sehingga membutuhkan solusi yang tepat.

\section{DAFTAR PUSTAKA}

Arikunto, S. 2003. Dasar-dasar Evaluasi Pendidikan (Edisi Revisi). Jakarta:

Jurnal Ilmiah Pembelajaran Sekolah Dasar Available online at:http://ojs.uho.ac.id/index.php/jipsd
Asma, N. 2006. Model Pembelajaran Kooperatif. Jakarta: Departemen Pendidikan Nasional

Dimyati dan Mudjiono. 2002. Belajar dan Pembelajaran. Jakarta: Rineka Cipta.

Hamalik, O. 2003. Proses Belajar Mengajar. Bandung: Bumi Aksara..

Hasmudin, E. 2012. Penerapan Metode Pemecahan Masalah untuk Meningkatkan Hasil Belajar Siswa Kelas VC pada Materi Pecahan Di SDN 01 Poasia (Skripsi S1 Tidak Diterbitkan). Kendari : FKIP Unhalu.

Kusumah, W dan Dwitagama, D. 2010. Mengenal Penelitian Tindakan Kelas. Jakarta: Index.

Nasution, N dan Suryanto, A. 2007. Evaluasi Pengajaran. Jakarta: Universitas Terbuka.

Suryanto, A dkk. 2009. Evaluasi Pembelajaran di SD. Jakarta: Universitas Terbuka.

Paizaludin dan Ermalinda. 2014. Penelitian Tindakan Kelas. Bandung: Alfabeta.

Poewanti, E. dkk. Asesmen Pembelajaran SD. Jakarta: Departemen Pendidikan Nasional.

Wikipedia Bahasa Indonesia. Tujuan_Pembelajaran_Kooperatif 2 (Online),https://id.wikipedia.org/wiki/ Pembelajaran_kooperatif\#cite_note. (diakses 15 juni 2015). 